\title{
Urban mobility and COVID-19 in Brazil: Comparison between 2020 and 2021
}

\author{
Anderson da Costa Armstrong ${ }^{1}$ (D), Carlos Dornels Freire de Souza ${ }^{2 *}$ (D), \\ Márcio Bezerra Santos ${ }^{3}$ (1), Lucas Gomes Santos ${ }^{2}$ [D, Rodrigo Feliciano do Carmo ${ }^{1}$
}

\section{SUMMARY}

OBJECTIVE: The aim of this study was to analyze and compare the indicators of urban mobility and the number of new cases of COVID-19 recorded daily between 2020 and 2021.

METHODS: An observational study was carried out involving new cases of COVID-19 registered daily in the state of Pernambuco, Brazil between March 12, 2020 and March 28, 2021 and six indicators of urban mobility. For analysis, the study was divided into two periods: the first was composed of 295 days and represents the year 2020 and the second was composed of 86 days and represents the year 2021. Spearman's non-parametric correlation was used.

RESULTS: In 2021, the greatest reductions in relation to the baseline were observed in parks (-29.0) and in retail and recreation areas (-28.7). However, these reductions were smaller than those observed in the previous year, indicating a greater circulation of people in 2021 when compared with mobility in 2020. In contrast, in residential areas, there was a reduction in the percentage change in relation to the previous year (11.2 in 2019 and 7.6 in 2021). In grocery and pharmacy, there was an increase 1.8 times greater than that observed in 2020 (9.1 in 2020 and 17.0 in 2021). It is also noteworthy that the daily average of new cases almost doubled in value (753.4 in 2020 and 1409.1 in 2021).

CONCLUSION: More vigorous measures must be taken to adequately control the pandemic.

KEYWORDS: SARS-CoV-2. Coronavirus Disease-19. Urban health. Epidemiology.

\section{INTRODUCTION}

In late 2019, the city of Wuhan in China recorded an outbreak of a rapidly progressing pneumonia. On January 7, 2020, the disease was named coronavirus disease 2019 (COVID-19), and its causative agent was identified as severe acute respiratory syndrome coronavirus 2 (SARS-CoV-2) ${ }^{1}$. On March 11, 2020, the World Health Organization (WHO) declared the COVID-19 pandemic ${ }^{2}$. At that time, there were already more than 118,000 cases in 114 countries and more than 4,000 deaths ${ }^{3}$.
In Brazil, the first case of COVID-19 was confirmed on February 26, 2020 in the state of São Paulo ${ }^{4}$. Until March 5, national transmission appeared to be sporadic, with $85.3 \%$ ( $n=29 / 34$ cases) of confirmed cases being of imported origin 5 . However, on March 20, 2020, community transmission was evidenced $^{4}$. On April 26, 2021, 14 months after the confirmation of the first case, Brazil ranks third in the world in the number of cases (14.3 million cases) and second in the number of deaths $(392,200 \text { deaths })^{3}$.

\footnotetext{
'Universidade Federal do Vale do São Francisco, Program in Health and Biological Sciences - Petrolina (PE), Brazil.

${ }^{2}$ Universidade Federal de Alagoas, Program in Health Family, Department of Medicine - Arapiraca (AL), Brazil.

${ }^{3}$ Universidade Federal de Sergipe, Program in Health Sciences - Aracaju (SE), Brazil.

*Corresponding author: carlos.freire@arapiraca.ufal.br

Conflicts of interest: the authors declare there are no conflicts of interest. Funding: none.

Received on July 26, 2021. Accepted on July 27, 2021.
} 
In Pernambuco, northeastern Brazil, the first cases were registered on March 12, initially individuals with a history of travel to Italy ${ }^{6}$. The large flow of individuals, the circulation between neighboring cities, and the urban agglomeration observed in the metropolitan region of Recife and in the Zona da Mata region may have been decisive factors for the acceleration of the pandemic in the state of Pernambuco ${ }^{7}$. As of April 30,2021 , the state recorded 406,500 cases and 14,000 deaths from COVID-194.

In the absence of proven effective drugs against COVID-19, non-pharmacological measures have been implemented as alternative behavioral pathways with the aim of slowing down the spread of the virus ${ }^{8}$. Among the set of measures implemented is the restriction of urban mobility, which is pointed out as a viable alternative since the transmission of coronavirus is highly dependent on the spatial behavior of individuals. Therefore, this study aimed to analyze and compare the indicators of urban mobility and the number of new cases of COVID-19 recorded daily between 2020 and 2021 .

\section{METHODS}

An observational study was carried out involving new cases of COVID-19 registered daily in the state of Pernambuco, Brazil between March 12, 2020 and March 28, 2021 and six indicators of urban mobility as follows:

i. mobility trends in retail and recreation (restaurants, cafes, shopping centers, theme parks, museums, libraries, and movie theaters),

ii. mobility trends in grocery and pharmacy (grocery markets, food warehouses, farmer markets, specialty food shops, drug stores, and pharmacies),

iii. mobility trends in parks (national parks, public beaches, marinas, dog parks, plazas, and public gardens),

iv. mobility trends in transit stations (public transport hubs such as subway, bus, and train stations),

v. mobility trends in workplaces, and

vi. mobility trends in residential areas. Data regarding new cases of COVID-19 were obtained from consolidated records from the Ministry of Health and State Health Departments (https://covid19br.wcota.me/), and mobility data were obtained from Google community mobility report (https:/www.google.com.br/covid19/ mobility/).

The mobility indicators consider the daily percentage change in relation to a baseline. The baseline value is defined by the median of the corresponding weekday over the 5-week period (from January 3 to February 6, 2020). This means that this baseline concerns an urban mobility pattern before the entry of SARS-CoV-2 in the region. The closer to the baseline, the more the movement of people in the places approaches a pattern considered normal, that is, before the pandemic. Positive values (above the baseline) represent an increase in the circulation of people in the places, and negative values represent a reduction in circulation in relation to that same baseline.

For analysis, this study is divided into two periods: the first was composed of 296 days and represents the year 2020 (March 12, 2020 to December 31, 2020), and the second was composed of 86 days and represents the year 2021 (January 1 to March 28, 2021). The measures of central tendency (mean and standard deviation, SD) and dispersion (minimum and maximum) of the indicators studied were analyzed, and Spearman's non-parametric correlation was used to evaluate the relationship between the variations in mobility and the number of new cases of COVID-19. A 5\% significance level was considered. Since we used secondary data from the public domain, we did not need the approval of the Research Ethics Committee.

\section{RESULTS}

In 2020, the largest reductions from the baseline occurred in retail and recreation areas (-36.0; SD 21.9) and in parks (-32.9; SD 18.9). Positive mean values, i.e., increased movement of people compared with baseline, were observed in grocery and pharmacy areas (9.1; SD 23.9) and residential areas (11.2; SD 4.8). It should be noted that the average number of new cases registered daily in 2020 was 753.4; SD 533. In 2020, Spearman's correlation showed that the closer to the baseline (median person circulation observed in the period before the pandemic - January 3 to February 6, 2020) in retail and recreation areas (rho 0.187; $\mathrm{p}=0.001$ ), grocery and pharmacies (rho 0.291; $\mathrm{p}<0.001$ ), parks (rho 0.136; $\mathrm{p}=0.019$ ), transit stations (rho 0.149; $\mathrm{p}=0.001$ ) and workplaces (rho 0.185; $\mathrm{p}=0.001$ ), the greater is the number of new cases of COVID-19 registered daily. An inverse relationship was observed in mobility in residential areas (rho $-0.127 ; \mathrm{p}=0.030$ ), indicating that the more people circulating in these regions, the fewer new cases were registered on a day (Table 1 ).

In 2021, the greatest reductions in relation to the baseline were observed in parks (-29.0; SD 13.4) and in retail and recreation areas (-28.7; SD 12.2). However, these reductions were smaller than those observed in the previous year, indicating a greater circulation of people in 2021 when compared with mobility in 2020. In contrast, in residential areas, there was a reduction in the percentage change in relation to the previous year (11.2; SD 4.5 in 2020 and 7.6; SD 2.5 in 2021). In grocery and pharmacy, there was an increase 1.8 times greater than 
Table 1. Descriptive analysis and Spearman's correlation between urban mobility variation and registration of daily new cases of COVID-19. Pernambuco, Brazil, March 2020 to March 2021.

\begin{tabular}{|c|c|c|c|c|c|c|}
\hline & \multicolumn{3}{|c|}{$\begin{array}{c}\text { March 12, } 2020 \text { to December 31, } 2020 \\
\text { (296 days) }\end{array}$} & \multicolumn{3}{|c|}{$\begin{array}{c}\text { January 01, } 2021 \text { to March 28, } 2021 \\
\text { (86 days) }\end{array}$} \\
\hline & \multicolumn{2}{|c|}{$\begin{array}{l}\text { Descriptive } \\
\text { analysis }\end{array}$} & \multirow{2}{*}{$\begin{array}{c}\text { Spearman's } \\
\text { rank correlation } \\
\text { coefficient } \\
\text { December 03, } \\
2020 \text { to December } \\
31,2021\end{array}$} & \multicolumn{2}{|c|}{$\begin{array}{l}\text { Descriptive } \\
\text { analysis }\end{array}$} & \multirow{2}{*}{\begin{tabular}{|c|}
$\begin{array}{c}\text { Spearman's } \\
\text { rank correlation } \\
\text { coefficient }\end{array}$ \\
$\begin{array}{c}\text { January } 01,2021 \\
\text { to March } 28,2021\end{array}$ \\
\end{tabular}} \\
\hline & $\begin{array}{l}\text { Min- } \\
\operatorname{Max}\end{array}$ & $\begin{array}{l}\text { Mean } \\
\text { (SD) }\end{array}$ & & $\begin{array}{l}\text { Min- } \\
\operatorname{Max}\end{array}$ & $\begin{array}{l}\text { Mean } \\
\text { (SD) }\end{array}$ & \\
\hline $\begin{array}{l}\text { A - Retail and recreation } \\
\text { (percentage change from baseline) }\end{array}$ & $\begin{array}{c}-78.0 \\
5.0\end{array}$ & $\begin{array}{l}-36.0 \\
(21.9)\end{array}$ & $\begin{array}{c}0.187 \\
(p=0.001)\end{array}$ & $\begin{array}{l}-63.0 \\
-16.0\end{array}$ & $\begin{array}{l}-28.7 \\
(12.2)\end{array}$ & $\begin{array}{c}0.053 \\
(p=0.626)\end{array}$ \\
\hline $\begin{array}{l}\text { B - Grocery and pharmacy } \\
\text { (percentage change from baseline) }\end{array}$ & $\begin{array}{l}-58.0 \\
83.0\end{array}$ & 9.1 (23.9) & $\begin{array}{c}0.291 \\
(p<0.001)\end{array}$ & $\begin{array}{l}0.0 \\
35.0\end{array}$ & $17.0(7.8)$ & $\begin{array}{c}-0.038 \\
(p=0.727)\end{array}$ \\
\hline $\begin{array}{l}\text { C- Parks (percentage change from } \\
\text { baseline) }\end{array}$ & $\begin{array}{l}-74.0 \\
23.0\end{array}$ & $\begin{array}{l}-32.9 \\
(18.9)\end{array}$ & $\begin{array}{c}0.136 \\
(p=0.019)\end{array}$ & $\begin{array}{c}-63.0 \\
0.0\end{array}$ & $\begin{array}{l}-29.0 \\
(13.4)\end{array}$ & $\begin{array}{c}-0.174 \\
(p=0.106)\end{array}$ \\
\hline $\begin{array}{l}\text { D - Transit stations (percentage } \\
\text { change from baseline) }\end{array}$ & $\begin{array}{l}-67.0 \\
73.0\end{array}$ & $\begin{array}{l}-20.9 \\
(24.5)\end{array}$ & $\begin{array}{c}0.149 \\
(p=0.001)\end{array}$ & $\begin{array}{c}-41.0 \\
0.0\end{array}$ & $\begin{array}{l}-14.6 \\
(8.7)\end{array}$ & $\begin{array}{c}-0.029 \\
(p=0.787)\end{array}$ \\
\hline $\begin{array}{l}\text { E - Workplaces (percentage } \\
\text { change from baseline) }\end{array}$ & $\begin{array}{l}-68.0 \\
28.0\end{array}$ & $\begin{array}{l}-16.3 \\
(18.7) \\
\end{array}$ & $\begin{array}{c}0.185 \\
(p=0.001)\end{array}$ & $\begin{array}{c}-27.0 \\
6.0\end{array}$ & $-6.7(7.3)$ & $\begin{array}{c}-0.280 \\
(p=0.009)\end{array}$ \\
\hline $\begin{array}{l}\text { F - Residential (percentage change } \\
\text { from baseline) }\end{array}$ & $\begin{array}{l}-1.0 \\
24.0\end{array}$ & $\begin{array}{l}11.2 \\
(4.8)\end{array}$ & $\begin{array}{c}-0.127 \\
(p=0.030)\end{array}$ & $\begin{array}{l}5.0 \\
14.0\end{array}$ & $\begin{array}{l}7.6 \\
(2.5)\end{array}$ & $\begin{array}{c}0.27 \\
(p=0.805)\end{array}$ \\
\hline $\begin{array}{l}\text { G - Number of new cases of } \\
\text { COVID-19 }\end{array}$ & $\begin{array}{c}0.0 \\
2512.0\end{array}$ & $\begin{array}{c}753.4 \\
(533.3)\end{array}$ & - & $\begin{array}{l}215.0 \\
2786.0\end{array}$ & $\begin{array}{l}1409.1 \\
(597.4)\end{array}$ & - \\
\hline
\end{tabular}

Min: minimum; Max: maximum; SD: standard deviation.

that observed in 2020 (9.1; SD 23.9 in 2020 and 17.0; SD 7.8 in 2021). It is also noteworthy that the daily average of new cases almost doubled in value (753.4; SD 533.3 in 2020 and 1409.1; SD 597.4 in 2021). In 2021, only the indicator of social mobility in workplaces ( $\mathrm{rho}=-0.280 ; \mathrm{p}=0.009)$ showed an inverse relationship with the number of daily new cases of COVID-19 (Table 1).

It is important to note that mobility restriction measures are implemented at peak times of the pandemic and their effects will appear in the following 2-3 weeks. For this reason, it is not possible to have a perfect synchrony between mobility restriction and daily cases of COVID-19 since the effect on case reduction will occur after the intervention. In addition, case drops are observed on weekends due to a decrease in case notifications. Details of the daily variation in the time series are shown in Figure 1.

\section{DISCUSSION}

The changes in the correlations between social mobility indicators and the number of new cases of COVID-19 observed in the first three months of 2021 may indicate the changes in the dynamics of COVID-19 transmission in the region, caused by factors such as the beginning of vaccination of risk groups, the emergence of new variants, the loosening of social distancing measures, and even signs of a possible seasonality of COVID-19.

The first dose of vaccine against COVID-19 was applied in Brazil on January 19. On that date, many other countries had already started mass vaccination of the population, such as Israel, the United Kingdom, and the USA. The slow vaccination process in Brazil places it in the 67th place in the world ranking of countries that have applied at least one dose of the vaccine against COVID-19, totaling $13.71 \%$ of the population on April 30, 20219. The delay in the population's immunization may result in more new cases of COVID-19 and a greater chance of the appearance of variants, such as the one identified in the northern region of the country at the beginning of $2021^{10}$.

Scientific evidence reveals that the strains that circulate in Brazil, despite not being more virulent, have greater infectivity ${ }^{10}$. This facilitated transmission, associated with the lower social distance observed in 2021, may have increased the contagion, resulting in an increase in cases in $2021^{11}$. This may explain why we found no statistical significance in the relationship of new cases and social mobility in the year 2021, except in workplaces (rho -0.280; $\mathrm{p}=0.009$ ). There is no clear explanation as to the inverse relationship between mobility in workplaces in 


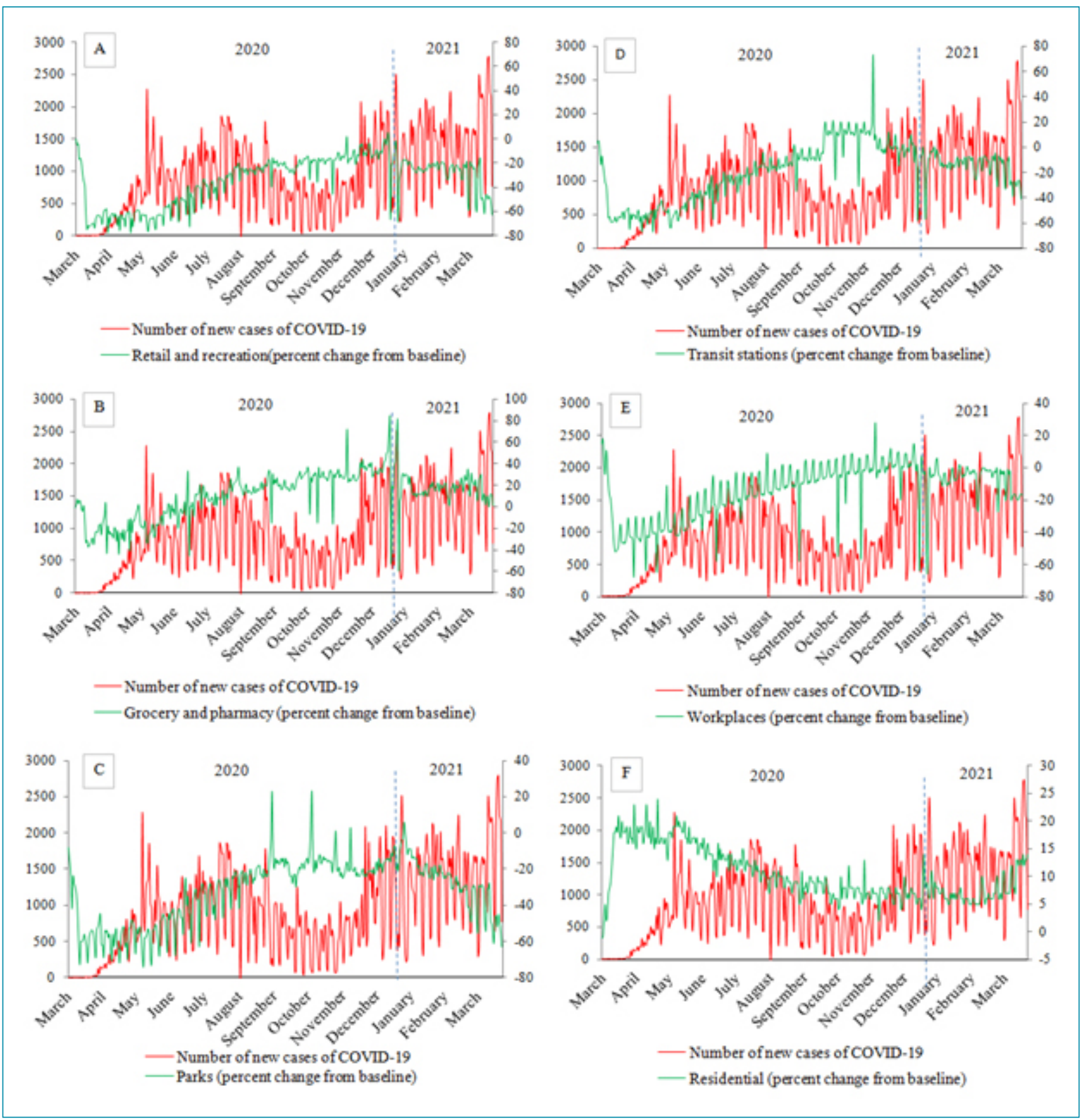

Figure 1. Temporal evolution of the daily variation of new cases of COVID-19 and urban mobility by sector. Pernambuco, Brazil, March 2020 to March 2021.

2021 with the daily number of cases. It is possible that there is a relationship with the opening of trade with health protocols and vaccination, although it is not possible to say, requiring detailed investigations in this regard.

Since the beginning of the pandemic in 2020, a series of non-pharmacological measures have been implemented to contain the transmission of the virus-remote work, school closures and remote education, reduced transportation flow, closure of nonessential services, and even more restrictive measures such as complete trade closures ${ }^{12}$. As a result, a greater circulation of people in residential areas and an inversion relationship with a lower number of cases was observed, given the impacts of these measures on the virus transmission chain. In contrast, in 2021, with the relaxation of the measures and the gradual return of 
commercial activities, there was a reduction in the movement of people in these areas.

Another important issue that occurred at the beginning of the pandemic was the increased circulation of people in pharmacies and drugstores. Among the factors associated with this dynamic are ${ }^{12-14}$

i. the fear of virus contamination (coronaphobia),

ii. the fear of a shortage of medications for continuous use,

iii. the search for treatments and/or prophylaxis disseminated through fake news, and

iv. the increased incidence of other emotional problems, such as anxiety, depression, and compulsive disorders, among others.

In addition, the emergence of new cases of COVID-19 may also be related to a possible seasonalization process of the disease. Although this study does not provide details about this hypothesis, due to the need for a larger time series than the one available, this characteristic is known for other viruses, such as $\mathrm{H} 1 \mathrm{~N} 1, \mathrm{H} 3 \mathrm{~N} 2$, and influenza $\mathrm{B}^{15}$.

\section{CONCLUSIONS}

The Brazilian epidemiological scenario - complex and dynamic - characterized by the greater circulation of people, delay in vaccination, emergence of new variants, use of clinical protocols not sanctioned by science, and the lethargy of the Brazilian government, we believe that the pandemic is still out of control and far from over. We hope that more energetic measures will be adopted in line with the scientific knowledge produced so far by scientists worldwide for adequate control of the pandemic in Brazil.

\section{AUTHORS' CONTRIBUTIONS}

ACA: Conceptualization, Writing - original draft, Writing - review \& editing. CDFS: Conceptualization, Data curation, Formal analysis, Writing - review \& editing. MBS: Conceptualization, Writing - review \& editing. LGS: Writing - original draft, Writing - review \& editing. RFC: Conceptualization, Formal analysis, Writing - original draft, Writing - review \& editing.

\section{REFERENCES}

1. Zhu N, Zhang D, Wang W, Li X, Yang B, Song J, et al. A novel Coronavirus from patients with pneumonia in China, 2019. N Engl J Med. 2020;382(8):727-33. https://doi.org/10.1056/ NEJMoa2001017

2. World Health Organization. Coronavirus disease 2019 (COVID-19): Situation Report - 51. [internet]. Geneva: World Health Organization; 2020. [cited on Apr. 26, 2021]. Available from: https://www.who.int/docs/default-source/ coronaviruse/situation-reports/20200311-sitrep-51-covid-19. pdf?sfvrsn=1ba62e57_10.

3. Johns Hopkins University. COVID-19 dashboard by the Center for Systems Science and Engineering (CSSE) [Internet]. Baltimore: Johns Hopkins University; c2020 [cited on Apr. 26, 2021]. Available from: https://coronavirus.jhu.edu/map.html

4. Rodriguez-Morales AJ, Gallego V, Escalera-Antezana JP, Méndez CA, Zambrano LI, Franco-Paredes C, et al. COVID-19 in Latin America: the implications of the first confirmed case in Brazil. Travel Med Infect Dis. 2020;35:101613. https://doi. org/10.1016/j.tmaid.2020.101613

5. Candido DDS, Watts A, Abade L, Kraemer MUG, Pybus OG, Croda J, et al. Routes for COVID-19 importation in Brazil. J Travel Med. 2020;27(3):taaa042. https://doi.org/10.1093/jtm/ taaa042

6. Brasil. Secretaria Estadual de Saúde de Pernambuco (SES). Boletim Epidemiológico COVID-19: dia 12 de março de 2020 [internet]. 2020 [cited on March. 20, 2021]. Available from: http://portal.saude.pe.gov.br/boletim-epidemiologico-covid-19

7. Carmo RF, Nunes BEBR, Machado MF, Armstrong AC, Souza CDF. Expansion of COVID-19 within Brazil: the importance of highways. J Travel Med. 2020;27(5):taaa106. https://doi. org/10.1093/jtm/taaa106
8. Flaxman S, Mishra S, Gandy A, Unwin HJT, Mellan TA, Coupland H, et al. Estimating the effects of non-pharmaceutical interventions on COVID-19 in Europe. Nature. 2020;584(7820):257-61. https://doi.org/10.1038/s41586-020-2405-7

9. Our Word in Data. Vaccinations [internet]. 2021 [cited on Apr. 30 2021]. Available from: https://ourworldindata.org/covid-vaccinations

10. Faria NR, Claro IM, Candido D, Franco LAM, Andrade PS, Coletti TM, et al. Genomic characterization of an emergent SARS-CoV-2 lineage in Manaus: preliminary findings. Science. 2021;372(6544):815-21. https://doi.org/10.1126/science.abh2644

11. Croda JHR, Garcia LP. Immediate health surveillance response to COVID-19 epidemic. Epidemiol Serv Saude. 2020;29(1):e2020002. https://doi.org/10.5123/S1679-49742020000100021

12. Valécio M. COVID-19 aumenta a venda de ansiolíticos para insônia e vitaminas [internet]. 2020 [cited on Feb. 2, 2021]. Available from: https://www.ictq.com.br/varejofarmaceutico/1552-covid-19-aumenta-venda-de-ansioliticosmedicamentos-para-insonia-e-vitaminas

13. Guimarães AS, Carvalho WRG. Desinformação, negacionismo e automedicação: a relação da população com as drogas "milagrosas" em meio à pandemia da COVID-19. JIMHA. 2020;3:e202003053. https://doi.org/10.31005/iajmh.v3i0.147

14. Nasir M, Chowdhury ASMS, Zahan T. Self-medication during COVID-19 outbreak: a cross sectional online survey in Dhaka city. Int J Basic Clin Pharmacol. 2020;9(9):1325-30. http://doi. org/10.18203/2319-2003.ijbcp20203522

15. Finkelman BS, Viboud C, Koelle K, Ferrari MJ, Bharti N, Grenfell BT. Global patterns in seasonal activity of influenza A/H3N2, A/H1N1, and B from 1997 to 2005: viral coexistence and latitudinal gradients. PLoS One. 2007;2(12):e1296. http:// doi.org/10.1371/journal.pone.0001296 